\title{
Perioperative Provider and Staff Competency in Providing Culturally Competent LGBTQ Healthcare in Pediatric Setting [Corrigendum]
}

Walia H, Banoub R, Cambier GS, et al. Adv Med Educ Pract. 2019;10:1097-1102.

The authors advised that there should be an added acknowledgment section. The authors apologize for this error. The acknowledgment section is as follows:

\section{Acknowledgment}

The authors would like to thank Equitas Health Institute for being part of our 2 part educational series on educating healthcare providers on LGBTQ issues referenced in the article. The perioperative environment is complex and stressful for our patients and families. It is vitally important for us to understand this vulnerable patient population to help them navigate through this experience.

\section{Publish your work in this journal}

Advances in Medical Education and Practice is an international, peerreviewed, open access journal that aims to present and publish research on Medical Education covering medical, dental, nursing and allied health care professional education. The journal covers undergraduate education, postgraduate training and continuing medical education including emerging trends and innovative models linking education, research, and health care services. The manuscript management system is completely online and includes a very quick and fair peer-review system. Visit http://www.dovepress.com/testimonials.php to read real quotes from published authors. 